\title{
Higher education faculty perception of service quality of Pakistan
}

\author{
Shaheen Fatima ${ }^{1, *}$, Samreen Fatima ${ }^{1}$, Nausheen Fatima ${ }^{2}$ \\ ${ }^{1}$ Hailey College of Commerce, University of the Punjab, Lahore, Pakistan \\ 2Institute of Quality and Technology Management, University of the Punjab, Lahore, Pakistan
}

\section{ARTICLE INFO}

\section{Article history:}

Received 24 April 2019

Received in revised form

14 July 2019

Accepted 18 July 2019

\section{Keywords:}

Service quality

Faculty perception

Private higher education institutions

Exploratory factor analysis

\begin{abstract}
A B S T R A C T
Faculty serves as stakeholders of higher education institutions (HEIs) and is responsible for knowledge creation and dissemination in society by imparting quality education. With an increase in commercialization of education in Higher Education Institutions more have been an area of concern for HEIs management. Various studies had been done in past on different stakeholders of HEIs and their perception of quality education but the purpose of the current study is to measure the service quality in private HEIs of Lahore, Pakistan by faculty perspective. Quantitative research methods of Principal Component Analysis and Rotated Component Matrix were used in the study. The sample of this study consists of 10 private sectors HEIs having campuses in Lahore. A questionnaire was used to collect primary data from faculty members of private HEIs. The questionnaire consists of 48 items divided into five dimensions of service quality i.e., Reliability, Tangibility, Responsiveness, Assurance and Empathy.204 questionnaires were completely filled and received from the faculty of 10 HEC recognized universities of Lahore. The value of Cronbach Alpha calculated for this study was 0.973. By using Rotated Component Matrix 40 out of 48 items were converged into eight factors as determinants of quality education from faculty' perception perspective while the remaining eight items having loadings less than 0.5 were not converged. Non converging items direct HEIs management to improve service quality in those ineffective and weak areas of service quality. This research study contributes towards policymakers, budget allocation committees and stakeholders of HEIs in formulating regulations for maintaining a competitive advantage.
\end{abstract}

(C) 2019 The Authors. Published by IASE. This is an open access article under the CC BY-NC-ND license (http://creativecommons.org/licenses/by-nc-nd/4.0/).

\section{Introduction}

Learning is a natural phenomenon of human beings. Efforts and contribution of teachers are required to catalyze this phenomenon of learning. To what extent students are satisfied with quality education and have learned. The answer to such a question needs a rigorous approach to measure the students' progress. In order to increase the effectiveness of the teaching-learning process, teachers should know students' performance. Based on such assumptions teachers will be in a position to update their teaching methodology, curriculum, assessment, etc. to achieve the educational goals.

Faculty plays an important role in the smooth and effective running of an education system. So the

\footnotetext{
* Corresponding Author.

Email Address: shaheenfatima344@yahoo.com (S. Fatima) https://doi.org/10.21833/ijaas.2019.10.002

(D) Corresponding author's ORCID profile:

https://orcid.org/0000-0003-1973-1973

2313-626X/C) 2019 The Authors. Published by IASE.

This is an open access article under the CC BY-NC-ND license

(http://creativecommons.org/licenses/by-nc-nd/4.0/)
}

faculty should be skillful in his profession to cope with the education system planning requirements. Role of education can be fruitful only if faculty properly manage and have specialization in their field to expand the knowledge. In Pakistan, educational management system does not cope with the national and local level needs of the education system. One of the reasons behind this is a lack of effective administrative structure in the education system. So it is the need of the hour to prepare faculty highly skillful and trained in their subject area specialization. It will help in the development and improvement of knowledge.

Change in technology in 21 century influenced not only on the structure of the industry but also on the nature of competition (Jahanbani, 2015). So the faculty of private sector HEIs should update their knowledge and professional skills in the competitive environment. Teaching is a multifaceted skillful profession in which teachers perform various roles other than teaching and imparting knowledge to students. 
Teaching is a process of imparting knowledge and information to students. There are various ways to impart knowledge but the best one is by which students easily understand it. Otherwise the goal of teaching will never be attained. Teaching process and role of faculty should be reconsidered in teacher students' relationship, teaching tools and techniques, rights and responsibilities of teachers, contents of curriculum, standards of assessments, professional trainings of teachers and working environment of higher education institutions. Faculty is responsible to help students in integrating their social, emotional and intellectual growth and to contribute to society, use knowledge in decision making. Objectives of the research study is:

- To measure faculty perception of service quality in private sector higher education institutions of Lahore.

- To assist HEIs management to maintain their quality standards up to national and international levels.

\section{Literature review}

Educational institutions are responsible and answerable to their external stakeholders for their strategic planning and goal settings (Bahrami, 2016). So the management of Higher education institutions should strive to focus more on their quality standards and goal settings. According to Anderson (1995) and Babakus and Boller (1992) Quality is defined as a strategic tool that is used to achieve operational efficiency and to improve organizational performance. According to Garvin (1987), Quality has eight dimensions: performance, features, reliability, conformity, durability, service, aesthetics and perception. While Lovelock and Wirtz (2004) argued that quality also includes following dimensions: delivery performance, responsiveness to the change in environment and market, the lowest possible cost in service.

Deming and Edwards (1982) defined quality as quality of design, quality of conformity and quality of performance. Garvin (1988) discussed evolution of "Quality" and explain five important perspectives of quality: Transcendent quality-view; Product based approach; User based approach; Manufacturing based approach and concept of value based on quality.

Service quality is the driving force for survival of organizations (Rust and Oliver, 1993). Service quality has been defined by various researchers. According to Zeithaml et al. (2006) and Parasuraman et al. (1985a), service quality includes following dimensions: Reliability, responsiveness, empathy, assurance and tangibility.

According to Parasuraman et al. (1985b), service quality is the difference between the expectations and perceptions of services by the customers. According to Tjiptono (2012), service quality is defined as "how a service meets the customer's expectations."
There are two major factors that influence the service quality: expectations and perceptions. If the perceived service is more than expectations than service quality is an ideal one and vice versa. Berry et al. (1990) stated that consumer has the sole authority to judge service quality, Parasuraman et al. (1985a) stated that consumer perceptions of service quality is the result of difference between consumer expectations and their actual experience of service. If the expectation exceeds perceived services, then the customer will be satisfied and delighted. Gronroos (1990) used the same approach and developed: Gap theory" concept based on perception minus expectations (P-E). Furthermore Gronroos (1990) stated that service quality has two components: Technical quality and Functional quality .Technical quality means what is offered during the service process (knowledge, tangibles, technical solutions etc.,). While on the other hand Functional quality means how the services are being provided, what are the interpersonal behavior of employees while encountering service. Kelley et al. (1990), furthermore added two components to service quality: Customer technical quality and customer functional quality. Customer technical quality refers to what consumer contributes while encountering service. On the other hand, consumer functional quality refers to how the consumer behaves during service provision process. Friendly, respectful and co-operative behavior is important in this regard.

\subsection{Perceived service performance}

Zeithaml et al. (1990) explained some factors which can influence consumer's perception of service quality. These are: tangibles, perceived competence and credibility of service providers and their responsiveness, reliability and courtesy. Cronin and Taylor (1992), stated that perceived service quality leads to consumer satisfaction, on the other hand Parasuraman et al. (1988) argued that consumer satisfaction leads to perceived service quality. Bitner (1990) concluded that perceived service quality is the product of evaluations of number of service encounters. In case of HEIs, the service encountered by students is the encounters with office, staff, tutors, lecturers, Head of Departments etc. Service expectations play a vital role in consumer quality perceptions. Organizations should take suitable measures to manage such expectations. it involves informing consumers of what is possible and what is not possible and mentioning the reasons why (Parasuraman et al., 1985b; King, 1985; Zeithaml et al., 1990) factors that influence consumer expectations are communications, personal needs of consumers, past experience of the service, and external communication from the service providers.

\section{Methodology}

Quantitative technique of primary data collection was used in the study. Total of 21 private sector HEIs 
have campuses in Lahore. Only 10 universities were randomly selected for study which are recognized by Higher Education Commission of Pakistan as leading Higher Education Institutions HEIs and Degree Awarding Institutions DAIs. Questionnaire was adapted from the study of Abdullah (2006). A five point Likert scale was used to measure perception of faculty members of HEIs. Faculty included academic and non-academic staff. Faculty members participated in the study were from various academic background. They are on permanent as well as on visiting basis. Such Faculty members were serving in the same institute for last 5 years. Questionnaires were administered personally by visiting various campuses and also by using emails etc.204 questionnaires were returned completed. Least sample size must be greater than 5 times variables or 100 . Another justification is subjects to variable ratio should be greater than 3 . Sample size of this study fulfils the above two conditions. Items in each dimension of service quality and Cronbach Alpha were shown in Table 1.

Table 1: Items in each dimension of service quality and Cronbach Alpha

\begin{tabular}{ccc}
\hline Dimensions of Service & $\begin{array}{c}\text { Survey } \\
\text { Quality }\end{array}$ & $\begin{array}{c}\text { Alpha } \\
\text { Cronbach }\end{array}$ \\
\hline Reliability(REL.) & $1-13$ & 0.937 \\
Tangibility (TAN.) & $14-27$ & 0.946 \\
Responsiveness(RES.) & $28-35$ & 0.900 \\
Assurance (ASSR.) & $36-42$ & 0.927 \\
Empathy(EMP.) & $43-48$ & 0.869 \\
\hline
\end{tabular}

\section{Results}

\subsection{Descriptive statistics}

After reliability test for individual dimension of service quality, Table 2 shows descriptive statistics of five dimensions of service quality which shows assurance have highest mean value (3.6737) and responsiveness have lowest mean value (3.4338). While standard deviation of reliability is 0.90998 which is considered more consistent among five variables of service quality.

Table 2: Descriptive statistics

\begin{tabular}{ccc}
\hline Dimensions of Service Quality & Mean & Std. Deviation \\
\hline Reliability & 3.5935 & 0.90998 \\
Tangibility & 3.5200 & 0.98116 \\
Responsiveness & 3.4338 & 0.99463 \\
Assurance & 3.6737 & 1.00634 \\
Empathy & 3.4771 & 0.93158 \\
\hline
\end{tabular}

\subsection{Measures of sample adequacy}

Kaiser-Meyer-Olkin (KMO) and Barlett's test of sphericity are mostly used to measure the adequacy of data. The KMO value calculated in the study as shown in Table 3 is 0.936 which is marvelous for Factor Analysis. While the second technique of data adequacy is Barlett's test of sphericity which shows significant $P$ value 0.00 which is less than 0.05 as in Table 4.
Table 4 shows the KMO value is 0.936 which is marvelous as shown in Table 3 hence it proved that the data is suitable for Exploratory Factor Analysis and $P$ Value is also significant. So, the data is significant.

Table 3: KMO Sample adequacy values

\begin{tabular}{cc}
\hline KMO Values within & Comment \\
\hline 0.9 & Marvelous \\
0.8 & Meritorious \\
0.7 & Middling \\
0.6 & Mediocre \\
0.5 & Miserable \\
less than 0.50 & Unacceptable \\
\hline \multicolumn{2}{c}{ Table 4: KMO and Bartlett's test } \\
\hline Kaiser-Meyer-Olkin measure of sampling & 0.936 \\
adequacy & 8195.679 \\
Bartlett's test of Sphericity, Approx.Chi- & 1128 \\
Square & 0.000 \\
df & \\
Sig. &
\end{tabular}

\subsection{Exploratory factor analysis (EFA)}

Exploratory Factor Analysis is a multivariate statistical technique used to uncover a large set of variables in the study. EFA is basically a technique within Factor Analysis and its goal is to explicit the relationship among measured variables. Furthermore, this technique reduces the less important factors used in the study. Scree plot in Fig. 1 shows a flattening line and Eigen values falling below 1 which shows that the items included in the research study are converge into eight factors while remaining 8 items were not converge. Rotated component matrix shows that 40 out of 48 items (Appendix A) were converge into eight factors while remaining eight were not converge. Such non converging items are shown in Table 5.

\subsection{Principal component analysis}

Principal component analysis shows the cumulative percentage of variance and the Eigen's value $>1$. Eight factors were extracted having approximately $70.652 \%$ of total variance as shown in Table 6. All the cumulative values are greater than 1 . Factor loadings basically elaborate the strength and direction among factors used in the research study. It shows how strongly the factors influence the measuring variables. Appendix B (Table B1) shows a factor loading pattern having items load highly over one another factor (loadings greater than 0.50).

All the items used under the five dimensions of service quality including converging and nonconverging are shown in Appendix B. Rotated Component Matrix was used in this study and loading having values less than 0.50 were ignored because they are non-significant. Further, Appendix B shows 40 items which were converge into 8 factors while remaining 8 items were not converge. 
Table 5: Non converging items of service quality that elaborates weak areas of service quality in HEIs as per faculty perception and need to be focused by HEIs management

\begin{tabular}{cc}
\hline Labels/codes & Explanation \\
\hline REL7 & HEIs management set their pre-determined learning levels. \\
REL8 & Faculty focus on communication skills development among students \\
REL9 & HEIs faculty design the Course contents which are up to date and meet national and international standards. \\
TAN15 & Private HEIs campuses have attractive and impressive appearance. \\
TAN19 & University management allocates needy scholarships financial assistance for deserving students. \\
TAN26 & University provides comfortable furniture in the class rooms. \\
RES.35 & University faculty displays results within stipulated time. \\
\hline
\end{tabular}

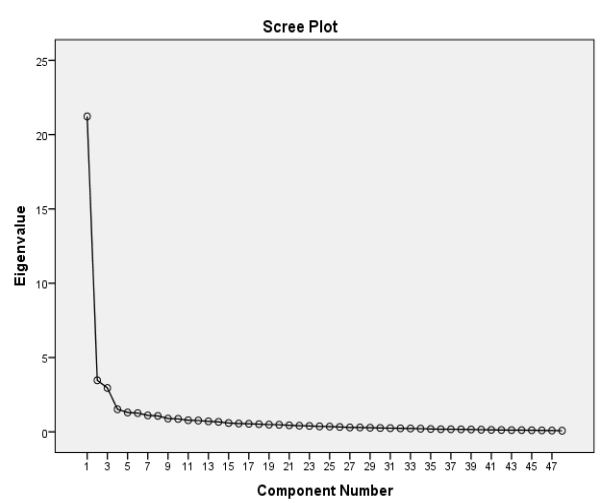

Fig. 1: Scree plot

Table 6: Extraction sum of squared loading; total and cumulative variance due to extracted factors

\begin{tabular}{ccc}
\multicolumn{3}{c}{ cumulative variance due to extracted factors } \\
\hline Factor & \% of variance & Cumulative $\%$ \\
\hline 1 & 44.221 & 44.221 \\
2 & 7.229 & 51.451 \\
3 & 6.149 & 57.600 \\
4 & 3.165 & 60.765 \\
5 & 2.714 & 63.478 \\
6 & 2.631 & 66.110 \\
7 & 2.305 & 69.415 \\
8 & 2.237 & 70.652 \\
\hline
\end{tabular}

\subsection{Non converging items}

40 out of 48 items were converging into eight factors while the remaining 8 were not converging. Such areas explicit the weaknesses in service quality of private HEIs according to faculty perceptions. Furthermore, they should be at top priority for HEIs management to improve service quality in such areas.

\section{Recommendations and conclusion}

Teachers make a remarkable contribution to any society. The role of teacher is important and it serves as a yardstick to access quality education. Purpose of current research study is to explore the determinants of faculty perception of quality education. By using Exploratory Factor Analysis, Principal component and Rotated matrix results depicts that 40 out of 48 items were converted into 8 factors whom loadings are greater than 0.50 while remaining 8 items were not converging. Such items are: Preparation of pre-determined educational levels, course contents up to date with national and international levels, development of communication skills among students, attractive university campus, need based scholarships, well equipped computer labs, availability of computer laboratories and display of students result within stipulated time period. Following are the recommendations on the basis of Non converging items:

- REL. 7: Faculty should focus on setting learning goals and designing strategies to assess whether goals achieved or not. Role of faculty is to set tasks and then evaluate the learners.

- REL. 8: Communication skills play a vital role in the learning process. Innovative teaching techniques and methodologies should be adopted by the faculty members to develop and improve communication skills among students.

- REL. 9: Faculty should adapt a course contents standard which is in collaboration with national and international levels. Course contents included goals, teaching methods and tools used evaluation of students learning, planning class assignment and exams.

- TAN. 15: Appearance of private HEIs campuses should be superficial. Faculty perceived that the management should focus on physical appearances of campuses. Management should set aside separate budget provision for physical attractive appearance of campuses.

- TAN. 19: University should provide financial assistance to needy, deserving and competent students on merit based.

- TAN. 24: Computer labs should have latest up to date computers and related technologies.

- TAN. 26: Classrooms should be well equipped with comfortable furniture.

- RES. 35: It is mandatory for faculty to administer and report results, test scores after evaluation of students within stipulated time.

Application of this study will assist faculty in overall effectiveness of quality education. As the role of teacher is indispensable in understanding and evaluating the effective way to achieve educational goals and learning among students. This research study has various limitations. It is limited to faculty perception of service quality. Data collection and responses are collected from private sector universities of Lahore.

Appendix A. The coding of the dimensions of service quality used in this study

\section{Reliability (REL.)}

REL. 1: Admission forms are provided at appropriate places in university campus. 
REL. 2: HEIs had prepared learning objectives of each module.

REL. 3: HEIs achieve their learning objectives by syllabus and class activities designed accordingly.

REL. 4: The curriculum should be in line with the requirements of the various degree programs.

REL. 5: students should be motivated to participate in teaching process.

REL. 6: Faculty /teachers should discuss relevant case studies during the lecture.

REL. 7: Pre determined learning levels.

REL. 8: Faculty should focus on development of students' communication skills.

REL. 9: Faculty and management of HEIs should design the Course contents up to date with national and international standards.

REL. 10: university management follows fair and unbiased assessment criteria.

REL. 11: Admissions on merit.

REL. 12: Fair entrance test according to test students' abilities and basic knowledge.

REL. 13: Students' counseling in selecting courses while getting enrolled.

\section{Tangibility (TAN.)}

TAN. 14: Prospectus includes complete details of all degree programs.

TAN. 15: University campus appearance is impressive.

TAN. 16: University campus is well equipped with medical facility centers.

TAN. 17: University provides transport to students at various routes of the city.

TAN. 18: Well-furnished hostels facility is provided to outstation / foreign students.

TAN. 19: University management should provide needy scholarships to deserving students.

TAN. 20: Library is well equipped with latest up to date books, journals, newspapers, newsletters etc.

TAN. 21: University is well equipped with laboratories.

TAN. 22: Lab facility is available for the students.

TAN. 23: Proper facility of latest computer labs along with major facilities in university campus.

TAN. 24: Computer labs are well equipped and up to dated.

TAN. 25: HEIs should focus on publications of research work of students.

TAN. 26: Availability of comfortable furniture in the class rooms.

TAN. 27: Well-equipped classrooms with multimedia or electronic boards etc.)

\section{Responsiveness (RES.)}

RES. 28: Faculty members ensure availability of courses outline along with their description and details on the university official website.

RES. 29: HEIs management should focus on providing online registration details of the students.

RES. 30: Faculty provides online Class notes and reading material regularly.

RES. 31: Class announcements or updates are informed to students via email etc.

RES. 32: Students should be given an opportunity to give their feedback regarding teaching methodologies and various facilities.

RES. 33: Management of HEIs should respond to students' queries quickly and promptly.

RES. 34: University management ensures availability of results on the official website of university.

RES. 35: HEIs management should display results within stipulated time.

\section{Assurance (ASR.)}

ASR. 36: University had well competent teaching faculty members.

ASR. 37: University had subjects' specialists' faculty members.

ASR. 38: Faculty members are foreign qualified and experienced.

ASR. 39: university faculty had up to date knowledge. ASR. 40: Proper SOP's are established for teaching, examination and admission processes.

ASR. 41: Administrative matters should be followed according to the university rules and regulations.

ASR. 42: There should be a fair evaluation procedure for quality and methodology of teaching.

\section{Empathy (EMP.)}

EMP. 43: University faculty is cooperative and supportive towards students' queries.

EMP. 44: Faculty is involved in promotion of academic culture.

EMP. 45: University had Alumni follow up services.

EMP. 46: Proper liaison is maintained between students and university management.

EMP. 47: university management gives weightage to the opinion of students.

EMP. 48: faculty is involved in celebrations of national events in university campuses.

\section{Appendix B. factor loading pattern}

Table B1: factor loading pattern having items load highly over one another factor

\begin{tabular}{|c|c|c|c|c|c|c|c|c|c|}
\hline \multirow{3}{*}{ Dimensions of service quality } & \multicolumn{9}{|c|}{ Rotated Component Matrix } \\
\hline & \multirow{2}{*}{ ITEMS } & \multicolumn{8}{|c|}{ Components } \\
\hline & & Factor1 & Factor 2 & Factor3 & Factor4 & Factor5 & Factor6 & Factor7 & Factor 8 \\
\hline \multirow{6}{*}{ Reliability } & REL.1 & & & .700 & & & & & \\
\hline & REL.2 & & & .767 & & & & & \\
\hline & REL.3 & & & .707 & & & & & \\
\hline & REL.4 & & & .753 & & & & & \\
\hline & REL.5 & & & .637 & & & & & \\
\hline & REL.6 & & & .508 & & & & & \\
\hline
\end{tabular}




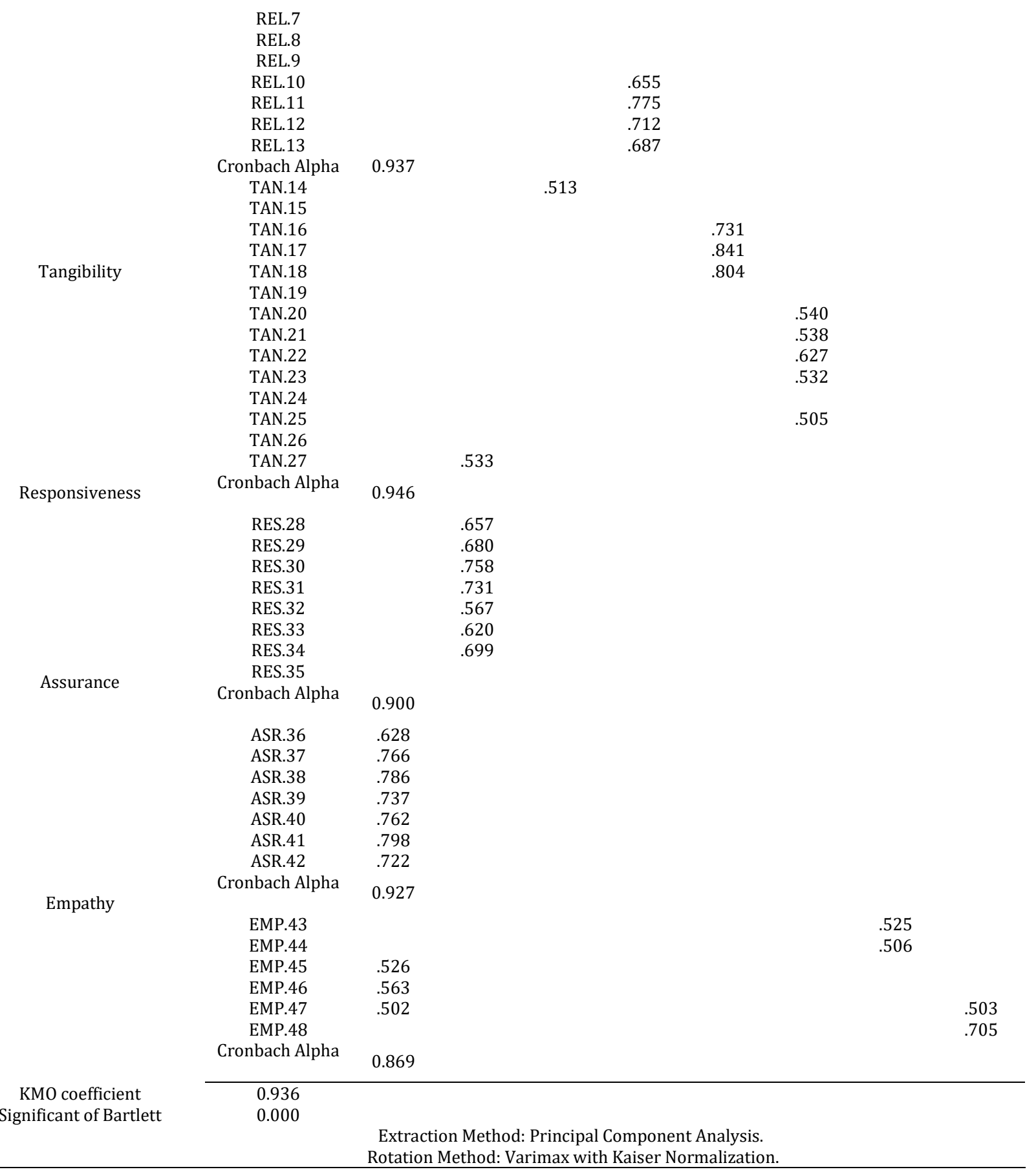

\section{Compliance with ethical standards}

\section{Conflict of interest}

The authors declare that they have no conflict of interest.

\section{References}

Abdullah F (2006). Measuring service quality in higher education: HEdPERF versus SERVPERF. Marketing Intelligence and Planning, 24(1): 31-47. https://doi.org/10.1108/02634500610641543

Anderson EA (1995). Measuring service quality at a university health clinic. International Journal of Health Care Quality Assurance, 8(2): 32-37.

https://doi.org/10.1108/09526869510081866

PMid:10142015
Babakus E and Boller GW (1992). An empirical assessment of the SERVQUAL scale. Journal of Business Research, 24(3): 253268. https://doi.org/10.1016/0148-2963(92)90022-4

Bahrami S (2016). Effect of organizational structure and corporate entrepreneurship in higher education. International Journal of Advanced and Applied Sciences, 3(2): 35-39.

Berry LL, Zeithaml VA, and Parasuraman A (1990). Five imperatives for improving service quality. MIT Sloan Management Review, 31(4): 29-38.

Bitner MJ (1990). Evaluating service encounters: The effects of physical surroundings and employee responses. Journal of Marketing, 54(2): 69-82. https://doi.org/10.1177/002224299005400206

Cronin JJ and Taylor SA (1992). Measuring service quality: A reexamination and extension. Journal of Marketing, 56(3): 5568. https://doi.org/10.1177/002224299205600304 
Deming WE and Edwards DW (1982). Quality, productivity, and competitive position. Massachusetts Institute of Technology, Center for Advanced Engineering Study, Cambridge, USA.

Garvin D (1987). Competing on the eight dimensions of quality. Harvard Business Review, 87: 101-109.

Garvin DA (1988). Managing quality: The strategic and competitive edge. Simon and Schuster, New York, USA.

Gronroos C (1990). Relationship approach to marketing in service contexts: The marketing and organizational behavior interface. Journal of Business Research, 20(1): 3-11. https://doi.org/10.1016/0148-2963(90)90037-E

Jahanbani K (2015). Effective factors on the acceptance mobile bank services from customers of Saderat bank branches in Rasht. International Journal of Advanced and Applied Sciences, 2(9): 1-7.

Kelley SW, Donnelly Jr JH, and Skinner SJ (1990). Customer participation in service production and delivery. Journal of Retailing, 66(3): 315-335.

King CA (1985). Service quality assurance is different. Quality Progress, 18(6): 14-18.

Lovelock C and Wirtz J (2004). Services Marketing: People, technology, strategy. Journal of Services Marketing, 18(5):
413-414.

https://doi.org/10.1108/08876040410548320

Parasuraman A, Zeithaml VA, and Berry LL (1985a). A conceptual model of service quality and its implications for future research. Journal of Marketing, 49(4): 41-50. https://doi.org/10.1177/002224298504900403

Parasuraman A, Zeithaml VA, and Berry LL (1985b). Quality counts in service, too. Business Horizons, 28(3): 47-52. https://doi.org/10.1016/0007-6813(85)90008-4

Parasuraman A, Zeithaml VA, and Berry LL (1988). SERVQUAL: A multiple-item scale for measuring consumer perc. Journal of Retailing, 64(1): 12-40.

Rust RT and Oliver RL (1993). Service quality: New directions in theory and practice. Sage Publications, Thousand Oaks, USA.

Tjiptono F (2012). Service management: Mewujudkan layanan prima. $2^{\text {nd }}$ Edition, Andi, Yogyakarta, Indonesia.

Zeithaml VA, Bitner MJ, Gremler DD, and Pandit A (2006). Services marketing: Integrating customer focus across the firm. McGraw-Hill/Irwin, Boston, USA.

Zeithaml VA, Parasuraman A, Berry LL, and Berry LL (1990). Delivering quality service: Balancing customer perceptions and expectations. Simon and Schuster, New York, USA. 